\title{
Low paraquat inhalation exposure for applicators spraying properly with knapsacks $^{1,2}$
}

\author{
James A. Singmaster, III ${ }^{3}$ and Lii-Chyuan Liu
}

J. Agric. Univ. P.R. 82(1-2):97-107 (1998)

\begin{abstract}
Four field experiments of knapsack applications with paraquat mixtures, some with oxyfluorfen, in plantain (Musa acuminata $\times$ M. balbisiana AAB) were conducted to evaluate paraquat inhalation exposure from mist for applicators, and to reduce the amount of inhalation. The first and second experiments used four adjuvant variables and four nozzle variables, respectively, with products which claimed to reduce mist. In all the analyses of applicators' respirators, paraquat was below the limit of detection (less than $0.018 \mathrm{mg}$ per respirator). As a check on this low level, two more experiments comparing two nozzles to spray paraquat, plus a standard adjuvant, were conducted under slightly different fieid conditions. Each applicator wore his respirator to spray three plots, instead of only one as before, to give a total exposure of $55.5 \mathrm{~L}$ per respirator. Analyses again showed paraquat below the detection limit of $0.025 \mathrm{ml}$ of spray per respirator, thus indicating that less than $0.018 \mathrm{mg}$ of paraquat ion reached the inhalation zone from nozzles held $1 \mathrm{~m}$ below. On the basis of less than $0.018 \mathrm{mg}$ of paraquat per respirator detected in these last two experiments, the inhalation exposure was less than $0.020 \mathrm{mg} / \mathrm{m}^{3}$. This level of paraquat inhalation exposure per applicator is well below $0.10 \mathrm{mg} / \mathrm{m}^{3}$, the listed limit of the $\mathrm{Na}$ tional Institute for Occupational Safety and Health (NIOSH). The standard analytical procedure for paraquat di-cation was used with a few modifications, the main one was to filter extracts from used respirators to remove microparliculates. Background absorbance before color reagent addition also had to be measured for subtracting from the absorbance with reagent, thus allowing detection down to $0.018 \mathrm{mg}$ of the paraquat di-cation.
\end{abstract}

Key words: paraquat, inhalation exposure, applicator, knapsack, detection

RESUMEN

Bajo nivel de exposición e inhalación de paraquat con el uso correcto de la bomba de mochila

Se realizaron cuatro experimentos de campo en donde se aplicaron mezclas de paraquat y oxifiuorfen, utilizando una bomba de mochila, al cultivo de plátano (Musa acuminata $\times$ M. balbisiana AAB) para evaluar la exposición

'Manuscript submitted to Editorial Board 15 March 1990.

2This research was supported in part by a grant SR-87-19-PR from Southern Regional

Pesticide Impact Assessment Program, USDA.

:Associate Researcher, retired, Department of Crop Protection.

'Researcher, Department of Crop Protection, Agricultural Experiment Station, P.O. Box 21360, Río Piedras, PR 00928. 
a inhalación de los aplicadores de paraquat, y determinar posibles medios de reducir la misma. En el primer experimento con cuatro adjuvantes y el segundo experimento con cuatro tipos de boquillas, el nivel de paraquat encontrado mediante análisis de los respiradores de los aplicadores estuvo muy por debajo del nivel de detección (menos de $0.018 \mathrm{mg}$ ). Para corroborar el bajo nivel de paraquat encontrado anteriormente, se llevaron a cabo dos experimentos adicionales comparando dos boquillas seleccionadas para aplicar paraquat más el adyuvante $X-77$ bajo condiciones de campo diferentes. Cada aplicador utilizó un respirador para asperjar tres parcelas, en lugar de una parcela, para un volumen total de $55.5 \mathrm{~L}$. Los análisis de los respiradores en estos dos experimentos revelaron que el nivel de paraquat estuvo por debajo del nivel de detección. Los resultados de estos dos últimos experimentos corroboraron que la exposición de los aplicadores al paraquat estaba por debajo de $0.10 \mathrm{mg} / \mathrm{m}^{3}$, el nivel establecido por el NIOSH. El método analitico para el di-catión de paraquat consistió en pasar los extractos de los respiradores por sus filtros para remover micropartículas. Se empleó una determinación estándar de colorimetria para detectar el nivel de paraquat por cada respirador. Se sustrajo la absorbancia sin añadir un reactivo de color desde la absorbancia con reactivo para poder detectar el nivel de paraquat a $0.018 \mathrm{mg}$.

\section{INTRODUCTION}

Paraquat ${ }^{5}$, until recently available in Puerto Rico in the Gramoxone Super ${ }^{6}$ formulation ICI Americas, is a restricted use contact herbicide registered for plantain and banana, important crops in Puerto Rico. Because of considerable acreage of these crops being grown by small farmers on uneven hillsides in Puerto Rico, much spraying with this formulation is done by knapsack, often without concern for inhalation risk from mist exposure. The Gramoxone Super label warns of the need to use an "approved face mask capable of filtering spray droplets" if risk of exposure to spray mist occurs.

A literature review revealed no prior studies on inhalation exposure risks for workers using knapsacks to spray paraquat. Two old reports (Chester and Ward, 1984; Swan, 1969) on paraquat sprays with knapsacks in several tests at one location detected no immediate health effects under zero wind, and some health effects not described in one test with some wind, but no measurements of inhalation exposure were mentioned. Because of trade winds common to Puerto Rico, this one test indicated a need to check on mist inhalation exposure. Workers here usually start spraying with little wind early in the morning but

"1,1-Dimethyl'-4,4'bypiridinium as ion, Chem. Abst. No. 4685-14-7 as dichloride salt, Chem Abst. No. 1910-42-5.

'Later, paraquat was reformulated by ICI Americas and given a new trade name, Gramoxone Extra. Consequently, use pattern may be changed from that for Gramoxone Super. The use of a trade name is to provide specific data on materials used and does not constitute an endorsement or warranty over other products not mentioned by the Agricultural Experiment Station or the authors. 
finish an acre near noon, when winds become active at many locations. With the last two to three sprayings after eight or more 19-L knapsack loads, workers on steep hillsides may be doing much open mouth breathing, thus trapping considerable mist in mouth mucous and swallowing non-respirable droplets. This aspect of "inhalation" may cause exposure risk different from that shown in one study (Chester and Ward, 1984). They found the respirable droplet fraction of spray mist to be a very low percentage of the total. Consequently, experiments to evaluate this "total inhalation" exposure for workers spraying by knapsacks were needed to determine whether farmers and workers should be using respirators for protection from mist exposure when the wind picks up.

The initial two experiments in this study address the problem of phytotoxicity from spray mist drift, with a recommended mixture of paraquat and oxyfluorfen formulations for use in plantains (Estación Experimental Agrícola, 1995). This research was prompted by visual observation of drift damage with this spray mixture (Liu, unpublished). Since drift damage might mean inhalation risks as well, the project as begun was directed toward controlling drift of spray mist by chemical or physical means as reported in the literature (Bouse and Leevskov, 1973; Bouse et al., 1976; Burnside, 1968; Butler, 1969; Shappell, 1986). Analyses of approved respirators worn by workers for paraquat mixtures sprayed in controlled experiments could show to what extent, if any, the chemical or physical means of drift control can reduce inhalation exposure of spray mist. Since the results from the first two experiments showed no detectable paraquat from mist on respirators and minimal phytotoxic effects from drift in the plantains and in an adjacent crop of taniers (Liu and Singmaster, 1990), the approach of the project was changed by conducting two more experiments with four times the regular paraquat X-77 spray being applied for respirator exposure to determine the level of paraquat inhalation exposure from a larger volume of spray.

\section{MATERIALS AND METHODS ${ }^{7}$}

Field Experiments:

Four experiments were established on two adjacent fields at the Corozal substation located in the north central part of upland Puerto Rico at an elevation of about $200 \mathrm{~m}$ above sea level. They were selected

'The work reported here followed label use pattern which was in effect at the time of the work but which may be changed by time of publication. The user of any purchased pesticide must read and follow the stated use pattern on the container's label. 
on an upwind side of a knoll near the top exposed to generally easterly winds and had some sheltering by trees further down the knoll 15 to 20 $\mathrm{m}$ to the east of the nearest plots. The field to the north had a slope of 20 to $30 \%$. This field was almost square allowing a $4 \times 4$ minus one corner for plot pattern with three replicates of five treatments for experiments No. 1 and No. 3. The field to the south had a 15 to $20 \%$ slope. This field was rectangular allowing a $3 \times 5$ plot pattern for experiments No. 2 and No. 4, the latter of which was done on a $3 \times 4$ plot pattern after cutting down plants in the three center plots. Plots were positioned for experiments No. 1 and No. 2 to have drift move from plantains toward taniers planted on the west side of the plantain plots.

For experiment No. 1, a randomized completed block design with three replicates for five treatments was used. The corms of Maricongo cultivar were planted 7 July 1987; taniers, two weeks later. The plot size of $12.8 \times 13.7 \mathrm{~m}$ contained 42 plantain plants and 40 tanier plants. Plantains were planted $1.8 \mathrm{~m}$ apart in six rows of seven plants each and taniers $0.9 \mathrm{~m}$ apart in two rows of 20 plants each. The first tanier row was separated by $1.8 \mathrm{~m}$ from the downwind side of the adjacent plantain plot. A buffer row of plantains was maintained between plantain plots. The actual area treated with herbicides was $11 \times 11 \mathrm{~m}(0.012 \mathrm{ha})$ covering $6 \times 6$ plantain plants. The taniers were untreated and maintained weed free by manual weeding. The taniers were used as an indicator plant for evaluation of drift.

The basic treatment consisted of $56 \mathrm{ml}$ each Gramoxone Super $(680$ g paraquat/3.78 L) and Goal $1.6 \mathrm{E}^{8}$ in $14.2 \mathrm{~L}$ of water per plot. This is equivalent to Gramoxone Super at $4.7 \mathrm{~L} / \mathrm{ha}$ rate and Goal at $1.2 \mathrm{~L} / \mathrm{ha}$. The treatment variables were drift control agents; Bivert ${ }^{9}$ (amine salts of organic acids plus other organic compounds), Orthotrol ${ }^{10}$ (polyvinyl polymer), Poly control" (polyacrylamide copolymer), X-77'12 (akylarylpolyoxy-ethylene glycols plus other organic compounds), and none. These adjuvants, Bivert at $14.0 \mathrm{ml}$, Orthotrol, Poly Control, or X-77 at 7 to $8 \mathrm{ml}$ (rough measure due to the viscosity), were added to the herbicide mixture according to recommended procedures. Different treatments in the same replicate were applied simultaneously by five persons with CP-3 plastic knapsack sprayers 27 August 1987. The five

"Registered trade mark, Rohm and Haas Co., for its product containing the active ingredient, oxyfluorfen [2-chloro-1-(3-ethoxy-4-nitrophenoxy)-4-(trifluoromethyl) benzene] Chem. Abst. No. 42874-03-3.

9Registered trade mark, Stull Chemical Co., to whom the authors express thanks for the sample tested.

"Registered trade mark, Chevron Chemical Co., Ortho Division.

:Registered trade mark, JLB International Chemical Inc.

"Registered trade mark, Chevron Chemical Co, Ortho Division. 
persons doing the applications were rotated to spray other treatments in the randomized fashion in the second and third replicates, and each set of replicates was sprayed simultaneously. All applicators wore protective suits, goggles and boots. Approved respirators (3M No. 9920) were used to collect any herbicide mist that could be inhaled by applicators and changed after each replicate. Each collected respirator was placed in an individual plastic bag, and all were stored in a freezer for subsequent chemical analyses.

For experiment No. 2, the field was prepared and then was planted to plantains and taniers 13 August 1987. The same experimental design, size of plots and application method as in the first experiment were followed in this experiment. The basic treatment consisted of 56 $\mathrm{ml}$ of Gramoxone Super and Goal 1.6 E each plus 7 to $8 \mathrm{ml}$ of X-77 in 14.2 $\mathrm{L}$ of water per plot. This is equivalent to Gramoxone Super at 4.7 $\mathrm{L} / \mathrm{ha}$ and Goal at $0.6 \mathrm{~L} / \mathrm{ha}$. The treatment variables included four nozzles: LFR NY 280 (Delavan Co. ${ }^{13}$, Raindrop SS 1.0 (Delavan Co. ${ }^{13}, 2-$ 8002 LP SS nozzle (Spray System) ${ }^{13}$, and 2-8002 SS (Spray System) ${ }^{13}$. All applications were made 20 September 1987, following the same general procedure used in the first experiments with five treatments in each replicate being sprayed simultaneously. The collection of exposed respirators after each herbicide application was the same as in the first experiment.

Experiment No. 3 was established in the same field as the first experiment. This field had actively growing plantain plants and weeds reestablished in the eight months since first herbicide application. The plot size was slightly increased to $11.0 \times 12.8 \mathrm{~m}(0.014 \mathrm{ha})$ to include the border row. The treatment consisted of $80 \mathrm{ml}$ of Gramoxone Super and 10 to $11 \mathrm{ml}$ of X-77 as a sticker in $18.5 \mathrm{~L}$ of water per plot (equivalent to $5.7 \mathrm{~L} / \mathrm{ha}$ ) with two selected nozzles, Raindrop SS 1.0 and 2-8002 SS as variables. The experimental design was a randomized complete block with two replicates of three plots each. Each applicator using a single respirator sprayed the same treatment on three plots, one 18.5 $\mathrm{L}$ knapsack load per plot, to constitute a replicate. All herbicide treatments were applied 27 April 1988 and respirators collected as before to be stored in a freezer until analyzed.

Experiment No. 4 was established on the field of experiment No. 2 with modification from experiment No. 3 done by cutting down two border plantain rows from each end and eight rows from the three central plots to allow wind movement. Plot size was increased to $13.7 \times 14.7 \mathrm{~m}$ (0.020 ha) with addition of border and adjacent area. The basic treatment consisted of Gramoxone Super at $4.0 \mathrm{~L} / \mathrm{ha}$ with same nozzles as

${ }^{13}$ The authors express thank to the companies for supplying the nozzles tested. 
in the third experiment. The same randomized complete block design with two replicates was used. Each applicator using a single respirator again sprayed on three plots, one 18.5-L knapsack load to each. All applications were made 18 May 1988 and respirators collected as before.

Wind measuring equipment from Meteorology Research Inc. with recorder and power converter ${ }^{14}$ using a 12 -volt car battery was set up to be read at $0.75 \mathrm{~m}$ above ground in the experimental areas for the first three experiments. Only in experiment 2 was wind direction and speed recorded for the whole application period, as batteries died about halfway through the period in experiments No. 1 and No. 3. A hand held Dwyer wind meter was used in all four experiments and the anemometer of a nearby weather station, less than $1.0 \mathrm{~km}$ away, was also checked before and after experiments 3 and 4 to verify the general wind speed in the area. Application to the first replicate in experiment 2 was subjected to more variability in wind speed and direction than other applications because of the close passing of a small shower front causing splattering of rain during application. Otherwise, applications were made under fairly consistent weather conditions of intermittent cloudiness with wind somewhat variable, light (4 to $5 \mathrm{~km} / \mathrm{h}$ average) with moderate gusts and generally from the east. All sprays were made in the 9:30 am-12:00 pm period, and workers were instructed to spray directly downwards without raising nozzles above knee level.

Paraquat di-cation analysis:

Plastic gloves were worn to handle exposed respirators while cutting off the plastic clips for the straps and cutting the respirators with razors into several sections to place in jars for extraction. In experiments No.1 and No. 2 exhaust valves were removed by pulling the mask fabric away, but were included in experiments No. 3 and No. 4 because of some respired water in the valves. Initially, extractions for some recovery studies of samples from the experiments were done by placing $200 \mathrm{ml}$ of distilled water in a jar with a mask, but later $1 \%$ ammonium chloride (ACS grade) solution was used for extractions. The jars, 2-L lab reagent types, were closed and placed on an Eberbach reciprocal shaker set at 160 stokes per minute for at least $10 \mathrm{~min}$. At this point $9 \mathrm{ml}$ of extract can be analyzed by colorimetric procedure of Pack (1969) using background subtraction detailed below.

For the reduction of background due to suspended matter, the extracts from experiments No. 1 and No. 2 were passed through Millipore SepPak $\mathrm{C}_{18}$ cartridges that were in accordance with manufacturer's di-

"The authors thank the Puerto Rico Electric Power Authority for the loan of this equipment. 
rections. With both the filter and the cartridge, the first $5 \mathrm{ml}$ or more of extract passed through was discarded and a sample of $9 \mathrm{ml}$ or more was collected for the colorimetric step.

For the spray samples collected in experiment No. 1, one ml was diluted to $50 \mathrm{ml}$. A portion of this was subjected to the cartridge cleanup, after which $0.5 \mathrm{ml}$ was made to $9 \mathrm{ml}$ for the colorimetric step. These samples were done with distilled water since the high concentration involved caused no retention problem on the cartridges.

The colorimetric analyses involved transferring $9 \mathrm{ml}$ of extract of standard solution described above to $3.0-\mathrm{cm}$ cuvette for reading on a Beckman DB spectrophotometer at $600 \mathrm{~nm}$. This background reading was subtracted from the reading made $1 \mathrm{~min}$ after adding $1 \mathrm{ml}$ of sodium dithionite solution prepared according to Pack (1969). Standard curves were prepared with appropriate solutions made from measured amounts of dried (overnight at $110^{\circ} \mathrm{C}$ ) analytical grade $(99.4 \%$ ) paraquat dichloride supplied by the manufacturer ${ }^{15}$. In the $3 \cdot \mathrm{cm}$ cuvette, $1 \mu \mathrm{g}$ of paraquat in $10 \mathrm{ml}$ of solution had an absorbance of $0.027 \pm 0.003$ units.

Recovery studies were run by preparing field spray solutions using the formulations Gramoxone Super and Goal 1.6 E and one of the four drift control agents (Bivert, Orthtrol, Poly Control, or X-77) in the following proportions: to 1,000 units of tap water, four units of each herbicide and 0.5 unit of drift control agent except for one unit for Bivert (equivalent to $473 \mathrm{~L}$ of water with $1.89 \mathrm{~L}$ each of herbicide and $237 \mathrm{ml}$ of a drift control agent; exception was $473 \mathrm{ml}$ of Bivert). Whole respirators or halves were spotted with varying amounts of the spraying solutions from 0.020 to $1.0 \mathrm{ml}$, and several fortified ones were stored in the freezer for one week to check whether lowered recoveries occurred with sample respirators in freezer storage.

\section{RESULTS AND DISCUSSION}

Analytical method:

Initially, the standard colorimetxic procedure of Pack (1969) applied directly to water extracts of the respirators and the diluted spray solutions allegedly had problems with interferences from the oxyfluorfen formulation (Goal 1.6 E) and adjuvants. Analyses of spray solutions diluted less than 200 fold showed some turbidity due to polymers in three of the adjuvants causing high background absorbance. The simple $\mathrm{C}_{18}$ SepPak cartridge cleanup step retained most of the compounds in the Goal 1.6 E and adjuvants except the highly ionic paraquat, salt and re-

15The authors thank ICI America for supplying these samples. 
sulted in lower background absorbance with close to $100 \%$ recovery of the paraquat di-cation in the colorimetric analysis.

Later, with used respirators, microparticulates collected during the spraying were found to raise the background absorbance considerably, which was not reduced much by the SepPak cartridge treatment. In experiment No. 3, respirator backgrounds of 0.022 to 0.136 A.U. when extracts were filtered through Whatman 541 paper, were reduced to 0.010-0.033 A.U., when filtered through the more retentive S\&S 589 paper. Extracts of most respirators used by the sprayers had a slight off-color compared to clear extracts of new ones. The off-color may be due to trapped chemicals and particulates from exhalation possibly with amounts greatly increased from workers who smoked before doing these sprayings, as the background varied more than five fold. One respirator worn by a non-smoker in the laboratory area for twenty minutes, about the average time for spraying a knapsack load, was extracted to show no background increase over low background $(0.005$ to 0.01 A.U.) of new respirators.

In the color development analysis, the microparticulate dispersion was overcome by subtracting the absorbance measured before adding the sodium dithionate reagent. When the reagent was added to extracts in cuvettes, change in absorbance was seen only in samples with paraquat. As a check on the reagent possibly going bad on standing or being deactivated by microparticulates, the last respirator samples in several analyses had, after the reagent addition and reading, $0.1,0.2$ or $0.4 \mathrm{ml}$ of spray solution diluted 100 fold added to the cuvette. In all cases, absorbance increases were within a few percent of the expected; thus the reagent worked properly. Difficulty with high absorbance of an old sodium dithionate sample was found to be due to insoluble fine materials, and even with a fresh sample, 10 to 15 minutes of standing after mixing was required for absorbance of less than 0.005 A.U.

Recovery studies were initially done with various prepared spray solutions to detect $0.2 \mathrm{ml}$ of spray spread on a respirator, from which more than $90 \%$ of the paraquat di-cation was recovered with water extraction. When used respirators from experiment No. I showed no detectable levels, recovery studies down to $0.025 \mathrm{ml} /$ respirator indicated reduced recoveries due to retention on the SepPak cartridge and also on filter paper. The switch to $1 \%$ ammonium chloride solution stopped the retention to return recoveries above $80 \%$. A recovery study sample was done with a fortified respirator as part of analyses of each. set of used respirators from the four experiments. The recovery percentages were 120, 96, 104 and 97 for the first, second, third and fourth experiments, respectively. 
Analyses of used respirators:

As hinted previously, the analyses for paraquat on a total of 38 used respirators, 15 each from experiments No. 1 and No. 2, and four each from experiments No. 3 and No. 4, showed no detectable levels (less than $0.018 \mathrm{mg}$ ) of paraquat di-cation on any respirator. In experiments 1 and 2 , where one knapsack load of $14.2 \mathrm{~L}$ was sprayed for each respirator used, no more than $0.025 \mathrm{ml}$ of spray reached the respirators. This means that less than $0.0002 \%$ of the spray was in the inhalation zone under the conditions of experiments No. 1 and No. 2. With experiments No. 3 and No. 4, where one respirator was used by an applicator to spray three loads of $18.5 \mathrm{~L}$ each, again no more than $0.025 \mathrm{ml}$ of spray reached the respirators. In this case, with almost four times more volume $(55.5 \mathrm{~L}$ ) sprayed per respirator, less than $0.018 \mathrm{mg}$ of paraquat of the spray reached the inhalation zone during application.

Applications in all four experiments were made from 9:30 am to noon, when winds are generally at their highest. Wind measurements indicated that at $0.75 \mathrm{~m}$ above ground level, the velocity averaged 4 to $5 \mathrm{~km} / \mathrm{h}$ during the applications, with some gusts about $5 \%$ of the time to $8 \mathrm{~km} / \mathrm{h}$. A few brief gusts reached about $16 \mathrm{~km} / \mathrm{h}$ according to recordings made during experiments 1 to 3 . The laborers, all experienced knapsack applicators, heeded directions to spray directly downward without raising the nozzle above knee level (about $0.6 \mathrm{~m}$ above ground).

These results are obtained under certain restricted conditions that include, besides the direct downward spraying and light wind conditions, low pressure application (about $206 \mathrm{KPa}$ ), with weeds being treated before getting to $0.91 \mathrm{~m}$ or higher. With weeds exceeding said height, farmers may spray upward and thus cause themselves serious inhalation exposure not studied here. Obviously, some locations on hill tops and open plateaus may have winds brisker than those encountered in this work and therefore may present greater risks, probably more with drift than inhalation exposure. When two workers spraying in adjacent rows move along close to each other, inhalation exposure may be high especially for the one downward on the leeward side of a hill. Inhalation exposure in such a situations could be complicated, depending on workers' positions, so workers were never positioned close to each other in this study.

The original intent in this work had been to evaluate, in an experiment after the first two trials, a combination of the best chemical drift control agent with the best nozzle for control of mist drift to see whether the combination reduced inhalation exposure even more. The results from experiments No. 1 and No. 2 ended up showing that risks were below detectable levels for all treatments. Therefore, experiments 
No. 3 and No. 4 were conducted to increase by four fold the amount sprayed previously per respirator to see whether measurable levels of inhalation exposure occurred. Because of the laboratory finding that the Gramoxone Super and Goal 1.6E combination was not easily maintained in a uniform mixture with any one of the agents, plus a statement by a company representative for Gramoxone Super that the company was against Gramoxone Super being mixed with Goal 1.6E, experiments No. 3 and No. 4 used only Gramoxone-Super plus recommended X-77. In experiment No. 1 with the two herbicides plus drift control agents, samples were taken of spray from the nozzles half way through the application. Analyses showed all sprays at that point with paraquat concentrations within $3 \%$ of the prepared concentration ${ }^{16}$. In experiment No. 1, different spray mixtures were prepared in the knapsack with an agitator to maintain a uniform mixture ${ }^{17}$.

The results of this work fill a gap in application safety for paraquat spray by knapsack or by low pressure hand linehose as well where a laborer's inhalation zone is about one meter from the spray nozzle. Such a situation was not studied in other reports involving tractors (Byass, 1977; Lavy, 1983; Staiff, 1975) or airplane spraying (Chester and Ward, 1984; Seiber and Woodrow, 1981). One concern in this work was the total amount of mist in the inhalation zone, not merely the small respirable percentage considered in one study (Chester and Ward, 1984). Heavy exertion when spraying by knapsack on hillsides caused open mouth breathing, leading to possible trapping of non-respirable particles from the mist into mouth mucous to be ingested, thus greatly increasing the overall exposure risk to mist in such sprayings. Our results show that despite the close proximity of nozzles to the laborer's inhalation zone, less than $0.018 \mathrm{mg}$ of paraquat reaches the respirators. On the basis of breathing exchange of $15 \mathrm{~L} / \mathrm{min}$, twice the resting exchange (Clayman, 1995) during heavy physical exertion, a total of 0.9 $\mathrm{m}^{3}$ of air passed through each worker's respirator during the $60 \mathrm{~min}-$ utes of application. This makes the worker's inhalation exposure to paraquat less than $0.020 \mathrm{mg} / \mathrm{m}^{3}$, which is well below the limit of 0.10

${ }^{16}$ An attempt to check whether oxyfluorfen was at the prepared concentration in the same spray samples presented a problem with an isomer of chemistry similar to that of oxyfluorfen in the formulation. The manufacturer would not provide a clear procedure or a sample of isomer to analyze for oxyfluorfen concentration. Oxyfluorfen in the respirators was not analyzed, as the Goal $1.6 \mathrm{E}$ has no warning of the need for analysis. Being volatile, oxyfluorfen could be trapped as a vapor, not as part of the mist.

${ }^{17}$ The easy separation of Goal from the spray mix with paraquat may be the source of rumored drift damage. If the mix is not properly agitated, some separated Goal could be sprayed at much higher concentrations than intended. Oxyfluorfen, Goal's active ingredient, being somewhat volatile, could move as a vapor beyond over treated areas to cause damage as drift. 
$\mathrm{mg} / \mathrm{m}^{3}$ listed by NIOSH for Occupational Safety and Health for paraquat inhalation exposure (NIOSH, 1990).

The results of these four experiments indicate a low risk of inhalation exposure for knapsack sprayers from spray mist when proper application techniques are used. With usual weather conditions for knapsack spraying of paraquat in Puerto Rico and with the proper application techniques, persons applying paraquat do not appear to need respirators.

\section{LITERATURE CITED}

Bouse, L. F. and R. E. Leerskov, 1973. Drift comparisons of low-expansion foam and conventional sprays. Weed Sci. 21:405-409.

Bouse, L. F., J. B. Carlton and M. G. Merkle, 1976. Spray recovery from nozzles designed to reduce drift. Weed Sci. 24:361-365.

Burnside, O. C., 1968. A shielded tractor mounted sprayer for research plots. Weed Sci. 16:386-388.

Butler, B. J., N. B. Akesseon and N. E. Yates, 1969. Use of spray adjuvants to reduce drift. Trabs. ASAE 12:182-186.

Byass, J. B. and J, R. Lake, 1977. Spray drift from a tractor-powered field sprayer. Pesticide Sci. 8(12):117-126.

Chester, G. and R. J. Ward, 1984. Occupational exposure and drift hazard during application of paraquat to cotton. Arch. Environ. Contam. Toxicol. 13:551-563.

Clayman, C. Ed. in Chief, 1995. The human body, Dorling, Kinderetey, London, p. 141.

Estación Experimental Agrícola, 1995. Conjunto Tecnológico para la producción de plátanos y guineos. Revised Ed. Publicación 97. Univ. Puerto Rico, Río Piedras.

Lavy, T. L., J. D. Mattice and R. R. Flinn, 1983. Field studies monitoring worker exposure to pesticides. Special Technical Testing Publication 765. Amer. Soc. For Testing Materials, Phila. PA. pp. 60-74.

Liu, L. C. and J. A. Singmaster III, 1990. Herbicide drift control in plantains and taniers. J.Agric. Univ. P.R. 74:471-475.

National Institute for Occupational Safety and Health, 1990. NIOSH Pocket Guide to Chemical Hazards, U.S. Government Printing Office, Washington, DC.

Pack, D. F, 1969. Paraquat. In: Analytical Methods for Pesticides, Plant Growth Regulators and Food Additives, pp. 475-81. Academic Press, New York.

Seiber, J. N. and J. W. Woodrow, 1981. Sampling and analysis of airborne residues of paraquat in treated cotton field experiments. Arch. Environ. Toxicol. 10:133-49.

Shappell, W. E., C. L. Foy, E. S. Hagood, Jx., R. C. Lambe and R. J. Stipes, 1986, Report to Technical Committee SRIEG on Advances in Pesticide Application Technology, Virginia Agric. Exp. Sta.

Staiff, D. D., S. W. Comer, J. S. Armstrong and H. R. Wolfe, 1975. Exposure to the herbicide paraquat. Bull. Environ. Contam. Toxicol. 14:334-40.

Swan, A. A. S., 1969. Exposure of spray operators to paraquat. Brit. J. Ind. Med. 26:32229 . 